\title{
DEGRADATION MODES OF ALLOY 22 IN YUCCA MOUNTAIN REPOSITORY CONDITIONS
}

\author{
Fred Hua \\ Bechtel SAIC, Las Vegas, NV 89131 \\ Gerald M. Gordon and Kevin G. Mon \\ Framatome ANP, Las Vegas, NV 89131 \\ Raúl B. Rebak \\ Lawrence Livermore National Laboratory, Livermore, CA, 94550
}

\begin{abstract}
The nuclear waste package design for Yucca Mountain (Nevada, USA), in its current configuration, consists of a double wall cylindrical container fabricated using a highly corrosion resistant Ni-based Alloy 22 for the outer barrier and type 316 stainless steel for the inner structural vessel. A mailbox-shaped drip shield fabricated primarily using Ti Grade 7 will cover the waste packages. The environmental degradation of the relevant materials have been extensively studied and modeled for over ten years. This paper reviews the state-of-the-art understanding of the degradation modes of Alloy 22 (N06022) due to its interaction with the predicted in-drift mountain conditions including temperature and types of electrolytes. Subjects discussed include thermal aging and phase stability, dry oxidation, general and localized corrosion, stress corrosion cracking and hydrogen induced cracking.
\end{abstract}

Keywords: Nuclear Waste Repository, Yucca Mountain Project, N06022, General Corrosion, Localized Corrosion, Stress Corrosion Cracking, Dust Deliquescence

\section{INTRODUCTION}

Radioactive materials are extensively used in a variety of applications such as medical, weapons, and power generation. Once these materials lose their commercial value, they are considered radioactive waste. Broadly, the nuclear wastes can be separated into defense (e.g. weapons) and civilian (e.g. power, medical). ${ }^{1}$ The safe disposal of radioactive waste requires that the waste be isolated from the environment until radioactive decay has reduced its toxicity to innocuous levels for plants, animals, and humans. One type of nuclear waste, denoted high-level waste (HLW), contains the highest concentration of radiotoxic and heat-generating species. Because of this factor, the most stringent standards for disposing of radioactive wastes are being placed worldwide on HLW, and the majority of the radioactive waste man- 
agement effort is being directed toward the HLW issues. One of the most common types of HLW is the spent fuel (SF) from commercial nuclear reactors for power generation.

All countries currently studying the options for disposing of HLW have selected deep geologic formations to be the primary barrier for accomplishing the isolation. ${ }^{2-3}$ It is postulated that due to the nature of these geological sites, the waste will be contained for long times, without spreading, for example, through water flow. Most of the repository designs also plan to delay the release of radionuclides to the environment by the construction of engineered barrier systems (EBS) between the waste and the geologic formation. The principal engineered component in this multibarrier approach is called the waste package that includes the waste, a stabilizing matrix for the waste (the waste and the matrix are together termed the wasteform), and a metallic container that encloses the wasteform. Beyond the metallic containers, other barriers could be added to attenuate the impact of the emplacement environment on the containers. These barriers include, for example, the drip shield proposed in the U.S. design or a bentonite backfill proposed in several European designs. ${ }^{2-3}$ The waste container may be a single vessel, but current designs generally call for concentric double walled vessels of dissimilar metals. Each vessel will have a specific function. For example, the container that directly holds the wasteform may be designed to shield radiation and facilitate safe waste handling and emplacement operations. This container may be over-packed with a corrosion-resistant outer layer.

In the U.S.A., the Nuclear Waste Policy Act of 1982 (as amended in 1987) designated Yucca Mountain in Nevada as the site to be characterized for high-level nuclear waste (HLW) disposal. Besides the materials degradation considerations, there are many other components in the Yucca Mountain Project (YMP) integrated modeling of the repository performance. The relationship of waste package and drip shield performance to the other components is illustrated in Figure $1 .{ }^{4}$ The nuclear waste package design for Yucca Mountain, in its current configuration, consists of a double wall cylindrical waste package fabricated using a highly corrosion resistant Ni-based Alloy 22 for the outer barrier and type 316 stainless steel (equivalent to Type 316 Nuclear Grade) for the inner structural vessel. A mailbox-shaped drip shield fabricated primarily using Ti Grade 7 will cover the waste packages. The purpose of this paper is to review the state-of-the-art in the studies of interaction between the in-drift environmental conditions and the Alloy 22 outer barrier of the container.

\section{EXPECTED ENVIRONMENTAL CONDITIONS IN THE REPOSITORY DRIFTS}

For the YMP repository design, the drifts where the waste packages will be installed in the mountain will operate in three temperature regimes: (1) the Dryout Regime, (2) the Transition Regime, and (3) the Low-Temperature Regime. Drift walls will first be dried by ventilation air during the pre-closure period. During the post-closure period, heat generated by radioactive decay will eventually increase the temperature of waste package, drip shield, and drift wall above the boiling point of water. In this dryout regime, no aqueous phase corrosion due to seepage is expected since seepage into the drift is prevented by the vaporization barrier effect. However, depending on the surface temperature and relative humidity conditions, the existence of liquid phase water on the waste package or drip shield is possible due to the presence of a dust or salt deposit. In the presence of such a deposit, a thin film liquid phase can be established at a higher temperature and lower relative humidity than otherwise possible. Thus, formation of deliquescent brines in the absence of seepage may occur. Corrosion of the waste package and drip shield should be considered in the context of these solutions.

Seepage into the drifts will become possible as the waste package cools into the so-called transition regime where the temperature of the drift wall drops below the boiling point of water, while the waste 
package surface temperature is at or above the boiling point of the water. Seepage waters will undergo evaporative concentration on the drip shield surface or the waste package surface at the time when the drip shield seepage diversion function is lost, thereby evolving predominately into either carbonate- or sulfate type brines with a much lower probability of forming calcium chloride type brines. The drip shield will mitigate seepage effects on the waste package and is expected to last through this period, unless there are low-probability seismic events that would shorten its performance lifetime. However, as in the dryout regime, formation of deliquescent brines could also occur in this regime.

The low temperature regime begins when the waste package surface cools to a temperature below the boiling point of water while the in-drift relative humidity increases, thus reducing the concentration of evaporative seepage brine solutions. With further cooling, the temperature will drop to below the threshold for localized corrosion for the repository-relevant environments. This threshold temperature is a function of the concentration of beneficial ions, such as nitrates and sulfates.

Figures 2 shows a representative time-temperature and time-relative humidity profile for a variety of waste packages (located near the center of the repository) in the three operational regimes and thermo hydrologic variables for the "hottest" waste package in the low-probability seismic collapsed drift scenario based on the current design. ${ }^{4,5,6}$

Earlier corrosion test studies on YMP focused on the carbonate type brine, based on reasoning that sodium carbonate type waters, as typified by J 13 well water from the saturated zone near Yucca Mountain, were the expected types of water at the repository. ${ }^{5,6,7}$ A later study showed that evaporative concentration of water based on a reported analysis of pore water from Yucca Mountain resulted in a calcium chloride-type brine. ${ }^{8,9}$ Geochemical literature establishes the three types of brines that result from the evaporative concentration of dilute natural waters at the earth's surface: (1) calcium chloride brine, (2) carbonate brine, and (3) sulfate brine. ${ }^{10}$ It is important to note that the compositions of brines are dependent on relative humidity, and the dominant ions in solution can and do change as a function of relative humidity. ${ }^{5,6} \mathrm{~A}$ range of environments has been projected to form within the repository due to water seepage. ${ }^{6}$ These water compositions have been grouped in bins or "water composition categories". The conditional probability (if seepage occurs at the drift crown for any particular location) that a type of water in a particular bin will form is also identified. ${ }^{6}$ For each bin, the associated brine and test solution in which corrosion testing was conducted are listed. ${ }^{6}$ In terms of brine type, the drift crown brines are predominantly the alkaline carbonate brines, although carbonate may not be a dominant component except at higher relative humidity. The composition of each bin water as a function of temperature and relative humidity is also documented. ${ }^{5,6}$ In addition to the seepage water brine types, the deliquescence of dust deposited on the waste packages and drip shields is another means by which brines can form on these engineered barrier system components. The associated brine types due to deliquescence of dust and the corresponding aqueous corrosion test solutions are also documented. ${ }^{6}$

Table 1 shows the composition of some of the solutions used for corrosion testing. ${ }^{11}$ These solutions were developed based on the evaporative concentration of a carbonate-based water with a composition based on J-13 well water, which is a saturated zone water near Yucca Mountain. The solutions represent various stages of evaporative concentration of this type of water. These aqueous solution compositions are concentrated to about 10 times (for SDW) to over 45,000 times (for SSW and BSW) to simulate evaporative concentration of the water upon contacting the waste package or the drip shield (Table 1). Other test solutions evaluated included $\mathrm{NaCl}$ solutions where $\mathrm{NaCl}$ concentrations varied from 0.5 to 4.0 molar; and $\mathrm{CaCl}_{2}$ and $\mathrm{CaCl}_{2}+\mathrm{Ca}\left(\mathrm{NO}_{3}\right)_{2}$ test solutions with $\mathrm{CaCl}_{2}$ concentrations up to 9 molar. In all cases, the $\mathrm{NO}_{3}{ }^{-}$component is the most soluble species and would dominate the solution composition at 
the deliquescent relative humidity or eutectic point of a mineral assemblage at elevated temperatures. The SSW and sodium chloride test solutions simulate the moderate relative humidity scenario where calcium is a minor component in the aqueous solution.

Corrosion test solutions corresponding to carbonate type of brine listed in Table 1 include the simulated dilute water (SDW), simulated concentrated water (SCW), basic saturated water (BSW), and under certain circumstances, the SSW and simulated acidified water (SAW). The BSW test solution is a highly concentrated alkaline solution and could be expected under repository conditions where temperatures could be at its measured boiling point of nominally $112^{\circ} \mathrm{C}$ to $113^{\circ} \mathrm{C}$ or where the relative humidity is nominally 70 to 75 percent. The SCW test solution is a moderately concentrated alkaline solution; solutions in this concentration range could be expected to form for relative humidity in the range of 90 to 95 percent. The SDW test solution is a dilute alkaline solution; solutions in this concentration range could be expected to form for high relative humidity (greater than 99 percent). These may have characteristics of solutions at the drift wall, that is, typical of seepage waters. Under conditions of extreme evaporative concentration (i.e., low relative humidity) the carbonate brine would evolve into a $\mathrm{Cl}^{-}-\mathrm{NO}_{3}{ }^{-}$brine with low carbonate content. The SSW test solution has characteristics of this type of brine. Likewise the SAW test solution has characteristics of low carbonate brine and would have characteristics of solutions in equilibrium with relative humidity of nominally 90 percent. The calcium and magnesium content of the SAW test solution tends to make it more able to sustain lower $\mathrm{pH}$ values due to the hydrolysis properties of these cations.

Corrosion test solutions corresponding to sulfate type of brine include the SAW, SSW, and sodium chloride. This type of brine has near neutral to slightly acidic $\mathrm{pH}$ and contains added magnesium which is not expected to be present in actual seepage waters to any significant extent. The SAW test solutions have characteristics of solutions in equilibrium with nominally 90 percent relative humidity. The SSW has characteristics of water that have undergone evaporative concentration to the extent that sulfate precipitates out of solution (this is for the magnesium free situation). Sodium chloride test solutions simulate the scenario where $\mathrm{Cl}^{-}$is the dominant anion under moderate relative humidity conditions.

\section{WASTE PACKAGE MATERIALS SELECTION}

The current design in Yucca Mountain Project for the waste package is based upon double-wall construction. ${ }^{12}$ The inner wall, made of Type 316 stainless steel with controls on carbon and nitrogen levels (equivalent to Type 316 Nuclear Grade), serves as a structural support. The corrosion-resistant waste package outer barrier is constructed from Alloy 22 (UNS N06022), a high-performance nickel-based alloy. Solution heat treatment of the as fabricated disposal container is used to remove fabrication-related residual tensile stress. ${ }^{13}$ After the waste package is filled with high-level radioactive waste or spent nuclear fuel, the stainless steel cylinder is sealed and two closure lids made of Alloy 22 will be remotely welded to the container outer shell by gas tungsten arc welding. Because residual weld stress at the closure welds might initiate stress corrosion cracking (SCC), a post-weld stress mitigation process will be used to reduce the tensile stress in the outer surface, thereby eliminating the stress initiator. The baseline stress mitigation process is laser shock peening. Figure 3 (a) shows a schematic illustration of the current design of the waste package.

Alloy 22 consists of 20.0 to 22.5 percent chromium, 12.5 to 14.5 percent molybdenum, 2.0 to 6.0 percent iron, 2.5 to 3.5 percent tungsten, 2.5 percent (max.) cobalt, 0.015 percent (max.) carbon, and balance nickel. ${ }^{14}$ Other elements present include phosphorus, silicon, sulfur, and manganese. The localized cor- 
rosion resistance of Alloy 22 is due to the additions of molybdenum and tungsten, both stabilize the passive film at low $\mathrm{pH} .{ }^{15}$ The oxides of these elements are insoluble at low pH. Consequently, Alloy 22 is highly resistant to localized attack. Very high repassivation potentials have been observed by some investigators, ${ }^{16}$ while others have found very low corrosion rates in simulated crevice solutions containing 10 weight percent $\mathrm{FeCl}_{3} .{ }^{17}$ Furthermore, no localized attack of Alloy 22 has been observed in creviced specimens exposed to water compositions representative of most of those expected in the repository (Table 1).

The titanium alloy drip shield is used to prevent seepage water, as well as rocks, from directly impinging on the waste package as schematically shown in Figure $3(\mathrm{~b})$. The drip shield will be installed in the stress-relieved condition, following emplacement of the waste packages in the drifts. The stress relief treatment is used to reduce fabrication-related tensile stress below the SCC initiation threshold. The drip shields will be fabricated using titanium alloys containing small palladium additions to provide corrosion resistance in the anticipated post-closure drift environment. Ti Grade 7 (UNS R52400), an alphaphase alloy, was selected for the plate material, which will be supported using higher strength welded ribs and bulkheads made from Ti Grade 24 (UNS R56405) (or Ti Grade 29 (UNS R56404), an alphabeta alloy. ${ }^{18}$ Similar to Alloy 22, based on laboratory test results, literature, and model predictions, these titanium alloys are expected to provide a high level of resistance to the various potential corrosionrelated degradation modes, including localized corrosion and hydrogen-induced cracking.

Systematic interactions between the in-drift environment and the drip shield and waste package outer barrier result in the occurrence of various degradation modes. ${ }^{4}$ These degradation modes are shown schematically in Figure 4. Each of the degradation modes shown in Figure 4 is operable to varying degrees, depending upon the temperature regime (Figure 2). For instance, in the pre-closure regime, the walls of the drifts will be kept dry by ventilation air, and no significant degradation of the waste packages is expected. In the post-closure dryout regime where temperature is greater than or equal to the boiling point of seepage water, potentially relevant high-temperature modes of degradation include dry oxidation and corrosion underneath deliquescent brines. In the transition regime where temperature is approximately the boiling point range of seepage water, seepage waters could concentrate on the waste package through evaporation if the drip shield were to fail. The potential modes of attack in these concentrated brines include uniform general corrosion, localized corrosion, stress corrosion cracking (SCC), hydrogen induced cracking ( $\mathrm{HIC}$ ) and other forms of degradation. Under the repository environmental conditions, microbially influenced corrosion (MIC) and radiation-assisted corrosion may also occur. It should be noted that not every degradation mode represented in Figure 4 may occur on either the waste package or the drip shield in the repository. For instance, the drip shield material (Ti Grade 7) is not subject to localized corrosion or MIC). In addition to these scenarios, other possible events that could lead to failure include seismic and volcanic activity. These scenarios are not discussed in this paper but examined elsewhere. ${ }^{19,20}$

\section{DEGRADATION OF WASTE PACKAGE OUTER BARRIER}

Aging and Phase Stability of Alloy 22

Alloy 22 is a meta-stable austenitic alloy, where secondary complex phases can be precipitated at high temperature. These topologically close packed (TCP) phases $(\mathrm{P}, \sigma$, and $\mu)$ are rich in those elements responsible for the exceptional corrosion resistance of Alloy 22. Therefore, precipitation of the second phases may cause depletion of the passivating elements in close proximity to the precipitates. Such de- 
pleted, localized areas may be more susceptible to corrosion than areas where no precipitation has occurred. Furthermore, these precipitates may deteriorate the mechanical properties of the alloy. In addition to the higher temperature complex phases, long-range ordering can occur at somewhat lower temperatures and could potentially negatively affect the SCC susceptibility.

YMP studies have included the use of multi-component phase diagrams and time temperaturetransformation diagrams together with experimental kinetic measurements as well as calculations of the rate at which deleterious phases (precipitates and long-range ordering) form at time-temperature combinations relevant to the repository. The studies and analyses show insignificant precipitation and long range ordering for the Alloy 22 under both mill-annealed and as-welded conditions during the 10,000 year simulation period, as long as the temperature is kept below $200^{\circ} \mathrm{C}$ (or $300^{\circ} \mathrm{C}$ for shorter times). ${ }^{21}$ The studies conservatively assume that the precipitation mechanisms that operate at higher temperatures also operated at much lower temperatures, and that the phases seen at the higher temperatures are also stable at the lower temperatures. Information from josephinite, a nickel-iron inter-metallic mineral phase that has been proposed as a natural analog for Alloy 22, shows the stability of metallic phases after exposure over millions of years. This is fully consistent with model predictions and experimental observations of no low temperature mechanism with rates significantly greater than those predicted at lower temperatures. This observation provides confidence in the implicit assumption that the high temperature mechanisms used to extrapolate kinetics are the same as those that occur at lower temperatures (approaching expected repository conditions).

The YMP model predictions and extrapolation of higher temperature results to lower temperatures show that formation of TCP or ordered phases in Alloy 22 base metal and annealed welds will not occur during a repository regulatory period well beyond 10,000 years. Further, analysis shows that TCP and longrange ordering phases would not form even for the unlikely case of early steady-state drift collapse (acting like backfill), where the waste package temperature could potentially increase to peak temperatures of about $300^{\circ} \mathrm{C}$, but for only relatively shorter times, decades to centuries. On this basis, neither the waste package outer barrier base metal nor weld metal is subject to enhanced degradation due to the effects of thermal aging. ${ }^{22}$ Therefore, the thermal aging process as a degradation mode is excluded from the total system performance assessment (TSPA) modeling in YMP.

\section{Structure and Properties of the Passive Film on Alloy 22}

The low general corrosion rates and localized çorrosion resistance of Alloy 22 depends on the long-term stability of a thin but adherent passive film. The passive film formed under aqueous condition has a stratified structure of at least two layers. ${ }^{23,24,25}$ The passive film consists of an inner layer of oxide, which acts as a barrier layer to corrosion and an outer layer of hydroxide or oxy-hydroxide, which plays the role of an exchange layer. ${ }^{25}$ In general, the chemical composition and thickness of passive films depend on the nature of the metal, the $\mathrm{pH}$ of the electrolyte in which the metal is passivated, and the electrochemical potential. ${ }^{23,24,25}$ For nickel, which can passivate in solutions over a wide range of $\mathrm{pH}$, the passive film is generally composed of $\mathrm{Ni}^{2+}$ cations with an inner layer of $\mathrm{NiO}$ and an outer layer of $\mathrm{Ni}(\mathrm{OH})_{2} .{ }^{25}$ The barrier layers on $\mathrm{Fe}-\mathrm{Cr}$ and $\mathrm{Ni}-\mathrm{Cr}$ alloys are primarily chromium oxide $\left(\mathrm{Cr}_{2} \mathrm{O}_{3}\right)$, but typically contain significant amounts of other metal species, such as $\mathrm{Ni}^{2+}, \mathrm{Fe}^{2+}$, and $\mathrm{Fe}^{3+}$ ions. ${ }^{26} \mathrm{Passive}^{2}$ films are generally not electronic conductors, but rather semiconductors or insulators. The passive film on chromium containing alloys is normally $n$ type in electronic character because the dominant defect in the film is either a cation interstitial or an oxygen vacancy, both of which are formally positively charged. ${ }^{27}$ 
The passive film formed on nickel can be crystalline, ${ }^{25}$ with the size and shape of the crystallites changing with applied potential. The passive oxide film formed on chromium can have a structure with oxide nano-crystals cemented together by the chromium hydroxide outer layer, yielding an extremely protective passive film. ${ }^{25}$ As summarized in the literature, ${ }^{23,24,25}$ the inner barrier layer of the passive film forms by the generation of oxygen vacancies at the metal-film interface, balanced in the steady state by dissolution of the barrier layer at the barrier layer-outer layer interface. The outer layer forms via the hydrolysis and precipitation of cations transmitted through the barrier layer or by hydrolytic restructuring of the barrier layer-outer layer interface. While both layers may incorporate alloying elements from the alloy substrate, only the outer layer incorporates species from the solution. The barrier layer grows into the substrate, whereas the outer layer grows outwards into the solution. ${ }^{23,24,25}$ Thus, while the growth of the inner barrier layer is due to the generation of oxygen vacancies at the metal-barrier layer interface, the growth of the outer layer is commonly due to the transmission of cations through the barrier layer, either through cation vacancies or as cation interstitials, and their eventual emission at the barrier layerouter layer interface. The outer layer may also form via hydrolytic restructuring of the barrier layer at the barrier layer-outer layer interface. ${ }^{23,24,25}$ Molybdenum (Mo) reduces the rate of anodic dissolution in the active state. ${ }^{25}$ Mo atoms tend to locate preferentially at local defects on the surface, which normally act as dissolution sites, and may decrease the dissolution rate by strengthening metal-metal bonds. ${ }^{25}$ Mo also counteracts the deleterious effect of species, such as sulfur, which can cause grain-boundary attack. Molybdenum bonds to sulfur and then dissolves mitigating the detrimental effects of sulfur. ${ }^{25}$

The point defect model (PDM) has been shown to account for the impact of Mo on the pitting resistance of $18 \mathrm{Cr}-8 \mathrm{Ni}$ stainless steels. ${ }^{27}$ Highly oxidized Mo ions present substitutionally in the inner barrier layer form immobile, positively charged centers. Substitution of $\mathrm{Mo}^{6+}$ into a chromium cation vacancy produces an immobile species with an effective +3 charge. These immobile species interact electrostatically with the mobile, negatively charged cation vacancies (with an effective -3 charge), the condensation of which at the metal-film interface is responsible for passivity breakdown. ${ }^{23,24}$ This solute vacancy interaction reduces the free cation vacancy concentration and diffusivity, which results in a positive shift in the breakdown voltage and a lengthening of the induction time for passive film breakdown to occur. ${ }^{25}$

\section{Dry Oxidation}

Dry oxidation of the waste package outer barrier occurs at any relative humidity below that at which a stable water film capable of supporting corrosion reactions is formed. ${ }^{22}$ Dry oxidation results in the formation of an adherent, protective oxide film of uniform thickness. The rate of dry oxidation is generally limited by mass transport. Measurements of the thickness of the Alloy 22 oxide film exposed to air at $550^{\circ} \mathrm{C}$ showed that the oxide film approaches a limiting thickness of about 0.025 to $0.050 \mu \mathrm{m}(25$ to $50 \mathrm{~nm}$ ) after about one-year of exposure. Dry oxidation is traditionally described by a parabolic rate law with an Arrhenius temperature dependence ${ }^{28}$

$$
x=A \cdot e^{\frac{E a}{2 R T \cdot t^{1 / 2}}}
$$

\section{(Equation 1)}

where $\mathrm{x}$ is the oxide thickness at time $\mathrm{t}, \mathrm{Ea}$ is the activation energy, $\mathrm{T}$ is the absolute temperature in Kelvin, $\mathrm{A}$ is a constant and $\mathrm{R}$ is the universal gas constant. A bounding analysis of the data for dry oxidation of several alloys presented by Welsch et al. leads to estimates of $\mathrm{A}$ and Ea of $18 \mathrm{~mm} / \mathrm{s}^{1 / 2}$ and $239 \mathrm{~kJ} / \mathrm{mol}$, respectively. ${ }^{29}$ For a temperature of $550^{\circ} \mathrm{C}$, an oxide thickness of about $0.26 \mathrm{~mm}$ is predicted after an exposure of 10,000 years. Clearly dry oxidation is not a performance limiting process in the repository. 


\section{General Corrosion}

As the thermal heat output from the radioactive waste decays with time, concentrated brines could form on the waste package surface either from evaporative concentration of dust leachates or, in case the drip shield is breached, the seepage water. ${ }^{22}$ In either case, hygroscopic salts may form on the waste package surface due to evaporative concentration of the leachate or the seepage water. Such hygroscopic salts enable aqueous solutions to exist as thin water films at relative humidity values below 100 percent. ${ }^{30}$ Creviced geometries could form between the waste package surface and structural components or mineral deposits from evaporative concentration processes. For this reason, the general corrosion and localized corrosion models are based for the most part on data from creviced specimens.

The general corrosion model for the Alloy 22 waste package outer barrier uses a rate distribution determined from weight-loss measurements of Alloy 22 creviced specimens that were exposed for over 5 years in a wide range of multi-ionic solutions at the project's Long Term Corrosion Test Facility (open circles in Figure 5) and a temperature dependence developed from shorter-term polarization resistance measurements. ${ }^{22}$ The general corrosion rate is conservatively assumed to be constant for a given temperature, knowing that the general corrosion rate of metals and alloys tends to decrease with time. The measured general corrosion general corrosion rates are fit to a Weibull distribution with a scale factor of $8.88 \mathrm{~nm} / \mathrm{yr}$ and a shape factor of 1.62 (the location parameter is set to zero). A plot of this Weibull distribution is shown in Figure 5 (the solid line fit the open circles). Arrhenius activation energy of about $26 \pm 2.5 \mathrm{~kJ} / \mathrm{mol}$ is determined from the polarization resistance data. Plots of the upper and lower bound (corresponding to the $+3 \sigma$ and $-3 \sigma$ values of the activation energy) general corrosion rate distributions at $25^{\circ} \mathrm{C}$ (red solid lines) and $125^{\circ} \mathrm{C}$ (green solid lines) are shown in Figure $5 .^{22}$

\section{Localized Corrosion}

The localized corrosion model is for the most part based on data from creviced specimens. ${ }^{22}$ This is a conservative treatment because localized corrosion initiation thresholds for crevice corrosion (i.e., critical chemistry and temperature) are lower than for pitting corrosion. Localized corrosion of Alloy 22 initiates when the open-circuit corrosion potential $\left(\mathrm{E}_{\text {corr }}\right)$ is equal to or greater than a critical potential $\left(\mathrm{E}_{\text {crit }}\right)$, i.e., $\Delta \mathrm{E}\left(=\mathrm{E}_{\text {crit }}-\mathrm{E}_{\mathrm{corr}}\right) \leq 0 .^{31,32,33,34,35,36,37}$ The repassivation potential (where the forward scan crosses the reverse scan) from cyclic potentiodynamic polarization (CPP) experiments is used as $\mathrm{E}_{\text {crit. }}$ Since creviced specimens were used, the critical potential is properly referred to as the crevice repassivation potential, $\mathrm{E}_{\mathrm{r}, \mathrm{crev}}$.

In the model, $\mathrm{E}_{\text {corr }}$ and $\mathrm{E}_{\text {crit }}$ are functions of temperature, $\mathrm{pH}$, chloride ion concentration, and nitrate ion concentration. The competing effects of chloride and nitrate ions on the crevice repassivation potential is represented with the ratio of the ion concentrations. $E_{r, \text { crev }}$ is defined as the sum of the crevice repassivation potential in solutions without $\mathrm{NO}_{3}{ }^{-}$ions $\left(E_{r, c r e v}^{0}\right.$ in Eq. 2 ) and the crevice repassivation potential change resulting from the addition of $\mathrm{NO}_{3}{ }^{-}$ions $\left(\Delta E_{r, c r e v} \mathrm{NO}_{3}^{-}\right.$Eq. 3). ${ }^{22,38}$

$$
\begin{aligned}
& E_{r, \text { crev }}^{0}=a_{0}+a_{1} T+a_{2} p H+a_{3} \log \left(\left[\mathrm{Cl}^{-}\right]\right)+a_{4} T \log \left(\left[\mathrm{Cl}^{-}\right]\right) \\
& \Delta E_{r, \text { crev }}^{N O_{3}^{-}}=b_{0}+b_{1}\left[\mathrm{NO}_{3}^{-}\right]+b_{2} \frac{\left[\mathrm{NO}_{3}^{-}\right]}{\left[\mathrm{Cl}^{-}\right]}
\end{aligned}
$$


The coefficients values and their \pm 1 standard deviation in Eq. 2 and Eq. 3 were determined to be: $\mathrm{a}_{0}=$ $214.089 \pm 46.880, \mathrm{a}_{1}=-3.696 \pm 0.476, \mathrm{a}_{2}=25.284 \pm 5.641, \mathrm{a}_{3}=-252.181 \pm 53.912$, and $\mathrm{a}_{4}=1.414 \pm$ 0.547 and $b_{0}=22.589 \pm 24.113, b_{1}=33.748 \pm 5.180$, and $b_{2}=749.745 \pm 95.491$.

The corrosion potential ( $\left.\mathrm{E}_{\text {corr }}\right)$ of Alloy 22 was found to increase over time in agreement with other studies. ${ }^{22,33,38,39}$ Therefore, only $\mathrm{E}_{\text {corr }}$ data with immersion times of 328 days and longer were used to develop the model. The functional form used to represent $E_{\text {corr }}$ is shown below:

$$
E_{\text {corr }}=c_{0}+c_{1} T+c_{2} p H+c_{3}\left[\mathrm{Cl}^{-}\right]+c_{4} \log \left(\frac{\left[\mathrm{NO}_{3}^{-}\right]}{\left[\mathrm{Cl}^{-}\right]}\right)
$$

The coefficients values and their \pm 1 standard deviation in Eq. 4 were determined to be: $\mathrm{c}_{0}=558.283 \pm$ $36.156, c_{1}=0.677 \pm 0.413, c_{2}=-65.338 \pm 2.456, c_{3}=-7.616 \pm 1.581$, and $c_{4}=37.077 \pm 2.443 .{ }^{22}$

Equations 2, 3 and 4 can be used to plot the values of $E_{\text {crit }}$ and $E_{\text {corr }}$ and determine according to the model described by these equations when localized corrosion could be possible in certain conditions for example of temperature and chloride concentration. Whenever $\mathrm{E}_{\text {corr }}$ is higher than $\mathrm{E}_{\text {crit }}$ localized corrosion is predicted to occur. If $\mathrm{E}_{\text {crit }}$ is always higher than $\mathrm{E}_{\text {corr }}$ localized corrosion is not possible according to the model.

The effect of $\mathrm{pH}$ on crevice corrosion initiation temperature is shown in Figure 6 for 10 molal (m, moles $/ \mathrm{kg}$ water) chloride ion solutions. At $\mathrm{pH} 7$ and low nitrate ion concentration $(0.5 \mathrm{~m})$ shown in Figure $6(\mathrm{a})$, crevice corrosion can initiate at temperatures as low as $50^{\circ} \mathrm{C}$, although initiation is improbable. The median temperature estimate is about $80^{\circ} \mathrm{C} .{ }^{22}$ For a higher nitrate ion concentration $(2.5 \mathrm{~m})$ shown in Figure 6(b), crevice corrosion is not likely to initiate even at temperatures as high as $120^{\circ} \mathrm{C}$. At $\mathrm{pH} 3$ and low nitrate ion concentration $(0.5 \mathrm{~m})$ shown in Figure 6(c), localized corrosion can initiate at ambient temperatures. For a higher nitrate ion concentration $(5 \mathrm{~m})$ shown in Figure $6(\mathrm{~d})$, crevice corrosion can initiate at temperatures as low as $90^{\circ} \mathrm{C}$, although initiation is improbable. The median temperature estimate is about $110^{\circ} \mathrm{C} .{ }^{22}$

\section{Stress Corrosion Cracking (SCC)}

SCC can occur when an appropriate combination of material susceptibility, tensile stress, and environment is present. ${ }^{28}$ In the case of Alloy 22 waste package outer barrier, SCC will possibly occur in the regions around the closure welds because the residual stress in the area cannot be relieved by processes such as bulk annealing, which could possibly damage the waste form. ${ }^{13}$ The residual stresses in all other areas of the drip shield and waste package outer barrier can be fully stress relieved by proper solution annealing. The effect of rock fall on the waste package is excluded from consideration because of the protection provided by the drip shield.

The YMP waste package outer barrier SCC model, ${ }^{13}$ which is based on the slip dissolution mechanism, ${ }^{40,41}$ assumes that crack growth can initiate at any surface defect (e.g., a grain boundary junction, scratch, and flaws introduced by the welding process) that can generate a positive stress intensity factor above the threshold. A threshold stress, below which SCC will not initiate on a "smooth" ${ }^{30}$ surface of $90 \%$ of the yield strength is used for initiation of these types of cracks. 
The slip dissolution model is used to calculate the crack propagation rate, $\mathrm{V}$, as a function of the local exposure environment (represented by parameter $\mathbf{n}$ for the repassivation rate at the crack tip) and the stress intensity factor, $\mathrm{K}_{\mathrm{I}}:{ }^{40,41}$

$$
V=\bar{A}\left(K_{I}\right)^{\bar{n}}
$$

where $\mathrm{V}$ is in $\mathrm{mm} / \mathrm{s}$ and $\mathrm{K}_{\mathrm{I}}$ in $\mathrm{MPa}(\mathrm{m})^{1 / 2}$. This equation is also used to develop a threshold stress intensity factor, $\mathrm{K}_{\mathrm{ISCC}}$, defined as the $\mathrm{K}_{\mathrm{I}}$, which results in a crack growth rate equal to the general corrosion rate. Parameters $\bar{A}$ and $\bar{n}$ in the above equation are related to the repassivation rate, $\mathrm{n}$, as follows:

$$
\begin{aligned}
& \bar{A}=7.8 \times 10^{-2} n^{3.6}\left(4.1 \times 10^{-14}\right)^{n} \\
& \bar{n}=4 n
\end{aligned}
$$

The hoop stress, which drives radially oriented cracks, is the dominant stress component in the waste package closure weld region. ${ }^{13}$ The hoop stress as a function of depth ( $\mathrm{x}$ in $\mathrm{mm}$ ) is given by a third order polynomial equation. The hoop stress state was also determined to vary with angle $(\theta)$ around the circumference of the waste package closure-lid welds. ${ }^{13}$ Figure 7 shows the hoop stresses of as-welded and laser peening stress mitigated outer lids. Figure 7 shows that stress mitigation imparts compressive stresses to the metal to a depth of approximately $3-4 \mathrm{~mm} .{ }^{13}$

The repassivation rate (slope), $\mathrm{n}$, is determined for Alloy 22 from Equation 6 based on crack growth rates measured under constant load conditions at various levels of applied stress intensity factor, $\mathrm{K}_{\mathrm{I}}$. ${ }^{13}$ The test data were developed from three Alloy 22 compact tension specimens tested at $110^{\circ} \mathrm{C}$ in a concentrated mixed salt environment representative of repository chemical environments. ${ }^{42,43} \mathrm{~A}$ crack growth rate of $10^{-11} \mathrm{~mm} / \mathrm{s}$ is used to represent the point where crack growth ceases. The mean value of the repassivation slope, $\mathrm{n}$, and the standard deviation are 1.304 and 0.160 , respectively. The lower and upper bounds of $n$, based upon 2 standard deviations $( \pm 2 \sigma)$, are 0.984 to 1.624 , respectively. ${ }^{13}$

Figure 8 shows the crack-growth rate as a function of stress intensity factor and for bounding values of the repassivation slope. Several crack growth curves are shown in the figure: the lower bound (n equal to 0.984 ), the mean (n equal to 1.304), and the upper bound (n equal to 1.624) for Alloy $22 .{ }^{13}$ It also indicates a crack growth rate dependency for the mean value for stainless steel (n equal to 0.54). In comparison to stainless steel, Alloy 22 has much higher resistance to SCC.

An effective approach to eliminate or delay the onset of SCC is to implement a post welding stress mitigation process to reduce residual tensile stresses below threshold values for SCC initiation and growth. The closure of the waste package outer barrier is designed to include two Alloy 22 lids (outer and middle). The outer closure lid weld region is laser-peened ${ }^{44}$ (or potentially mitigated by controlled plasticity burnishing) while the middle closure lid weld is untreated. Laser peening and controlled plasticity burnishing result in the formation of a compressive surface layer and thus delay the onset of SCC until this compressive layer is removed by general corrosion. 


\section{Hydrogen-Induced Cracking (HIC)}

Hydrogen generated at cathodic sites in a corroding metal may be absorbed into the metal and potentially form hydride phases. Hydrogen incorporation could lead to degradation of the mechanical properties of the material and render it susceptible to cracking even in the absence of the formation of hydride phases. Hydrogen-induced cracking results from the combined action of hydrogen and residual or sustained applied tensile stresses. The extremely low corrosion rates exhibited by nickel alloys are not sufficient to generate enough hydrogen to cause hydrogen-induced cracking. ${ }^{30}$ Fully annealed nickel-base alloys, such as Alloy 22, are essentially immune to hydrogen-induced cracking. ${ }^{30}$ For instance, Ni-Cr-Mo alloys with compositions and properties similar to Alloy 22 such as Alloys C-276 (UNS N10276), C-4, and Alloy 625 (UNS N06625) maintain their resistance to hydrogen-induced cracking even when heavily cold worked to yield strengths in excess of 1,240 MPa (180 ksi). ${ }^{30}$ Cold-worked Ni-Cr-Mo alloys are not susceptible to hydrogen-induced cracking unless they are galvanically coupled to a less noble material (or subjected to imposed cathodic current) and strained beyond yield. ${ }^{45,46}$ The further improvement in resistance to HIC of Alloy 22 is by annealing, but it is at the cost of reduction in strength. However, the structural requirements of the waste packages at Yucca Mountain are such that strengthening of the alloys is not required, ${ }^{45}$ since the structural requirements for the waste package are satisfied by the Type 316 stainless steel inner shell.

Aging of Ni-Cr-Mo alloys at temperatures around $500^{\circ} \mathrm{C}$ can lead to ordering or grain boundary segregation of deleterious elements such as phosphorous and sulfur, which may increase susceptibility to hydrogen-induced cracking. ${ }^{30}$ However, Asphahani tested cold worked (60 percent cold swaged) and aged $\left(500^{\circ} \mathrm{C}\right.$ for 100 hours) samples of Alloy C-276 at applied stresses up to $92 \%$ of yield and cathodic current densities of $40 \mathrm{~mA} / \mathrm{cm}^{2}$. No effect on HIC was found. ${ }^{46}$ Therefore, the scenario that the waste package outer barrier material fails due to the uptake of hydrogen and the formation of metal hydrides that may mechanically weaken the waste packages can be ruled out. ${ }^{47}$

\section{Effects of Gamma Radiolysis}

The effects of radiation on waste package materials corrosion differ depending on the amount of liquid present on their surfaces (i.e., humid air or aqueous conditions). Under humid air conditions, a thin film of liquid that may contain trace constituents (e.g., dissolved gases) forms. Irradiation of these films could lead to acidic conditions and to enhanced corrosion. Under aqueous conditions, anodic shifts in the open-circuit potential of stainless steel in gamma-irradiated solutions due to the formation of hydrogen peroxide have been experimentally observed. ${ }^{48,49,50}$ Note that Glass et al. ${ }^{49}$ and Kim ${ }^{50}$ worked on stainless steels, rather than Alloy 22, the latter being significantly more corrosion resistant. Although there is little information available in the literature on the effects of radiation on Alloy 22, some data are available on the corrosion of Alloy C-4, which is compositionally similar to Alloy 22. Gamma irradiation in aggressive $\mathrm{MgCl}_{2}$ brines showed that below approximately $100 \mathrm{rad} / \mathrm{hr}$, irradiation has no observable influence on the corrosion behavior of Alloy C-4. No enhancement of general corrosion and no pitting or crevice corrosion are observed in the material at these dose rates. ${ }^{51}$

Calculations of the expected radiation levels at the surface of the waste package have been performed. ${ }^{52}$ For a bounding case waste package containing 21 PWR spent nuclear fuel assemblies (80 GWd/MTU burnup and 5-year decay), the maximum surface radiation level was calculated to be about $1,170 \mathrm{rad} / \mathrm{hr}$ at the outer surface of the waste package shell and 1,650 rad/hr at the bottom lid of the shell. These values are at the time of emplacement. During the ventilation period of 50 years, no aqueous or humid air environment and therefore, no radiolysis is expected. After 50 years, the maxi-mum surface radiation 
level decreases to levels of less than $100 \mathrm{rad} / \mathrm{hr}$ for the outer surface and $80 \mathrm{rad} / \mathrm{hr}$ for the bottom lid and decrease steadily with time. ${ }^{52}$ Note that these are bounding radiation levels for the highest burnup spent nuclear fuel and are well below the levels at which some effect of radiation has been observed. Therefore, the effects of radiolysis on corrosion performance of Alloy 22 will not be significant under repository relevant conditions.

\section{Effect of Microbial Activity (MIC)}

Microbially Influenced Corrosion (MIC) is the contribution to the corrosion rate of a metal or alloy by the presence or activity, or both, of microorganisms. ${ }^{22}$ Microorganisms can affect the corrosion behavior of an alloy either by acting directly on the metal or through their metabolic products. For example, some types of aerobic bacteria may produce sulfuric acid by oxidizing reduced forms of sulfur (elemental, sulfide, sulfite), and certain fungi transform organic matter into organic acids. ${ }^{53}$ The waste package outer barrier is potentially subject to microbially influenced corrosion (MIC) when the relative humidity at the waste package surface is equal to or greater than 90 percent. ${ }^{22}$ The effect of MIC is represented by an enhancement to the abiotic general corrosion rate. ${ }^{22}$ It has been observed that nickel-based alloys such as Alloy 22 are relatively resistant to $\mathrm{MIC}{ }^{54}$

There are no standard tests designed specifically to investigate the susceptibility of an engineering alloy to MIC. ${ }^{55}$ One commonly used type of evaluation to determine the MIC factor is to test the alloy of interest in situ (field) using the same variables as for the intended application. However, testing in the laboratory with live organisms can provide more controlled conditions of various environmental variables, and sterile controls can be incorporated to better assess MIC specific effects. ${ }^{56}$ This approach was used in the YMP to evaluate the microbiological processes on general corrosion of the waste package outer barrier, with the effect of MIC being described as:

$$
C R_{M I C}=C R_{s t} \cdot f_{M I C}
$$

where $\mathrm{CR}_{\mathrm{MIC}}$ is the general corrosion rate in the presence of microorganisms, $\mathrm{CR}_{\mathrm{st}}$ is the general corrosion rate of the alloy in the absence of $\mathrm{MIC}$, and $\mathrm{f}_{\mathrm{MIC}}$ is the MIC factor. If $\mathrm{f}_{\mathrm{MIC}}$ is greater than 1 , there is an enhancement of the corrosion rate of the alloy as a consequence of the presence or activity of microorganisms. The project results obtained with polarization resistance measurements showed that MIC can enhance corrosion rates of Alloy 22 by a factor of at most two. It is assumed that the MIC factor $\mathrm{f}_{\mathrm{MIC}}$ is uniformly distributed between 1 and 2 , and that this distribution is totally due to uncertainty. ${ }^{54}$

Other environmental factors that could affect bacterial growth include temperature and radiation. These factors, however, are closely coupled to relative humidity; as temperature and radiation decrease in the repository, relative humidity is predicted to increase. At the same time, while there are some types of microorganisms that can survive elevated temperatures (less than or equal to $120^{\circ} \mathrm{C}$ ) and high radiation doses, if there is no available water, then bacterial activity is completely prevented. Thus, because water availability during the thermal pulse is the primary limiting factor and this factor is coupled to other less critical limiting factors, water availability (as expressed by relative humidity) was used as the primary gauge of microbial activity.

\section{Effects of Fluoride and Bromide Ions}

The effect of fluoride $\left(\mathrm{F}^{-}\right)$and bromide $\left(\mathrm{Br}^{-}\right)$ions on the corrosion behavior of Alloy 22 has not been as extensively investigated as the effect of chloride $\left(\mathrm{Cl}^{-}\right)$ions. ${ }^{57}$ There is no significant difference in pas- 
sive current densities for Alloy 22 in $1 \mathrm{M} \mathrm{NaCl}\left(\mathrm{pH}\right.$ 6) and $1 \mathrm{M} \mathrm{NaF} \mathrm{(pH} \mathrm{9)} \mathrm{at} 50^{\circ} \mathrm{C}$ but the breakdown potential was found significantly lower in $\mathrm{NaF}$, presumably due to the difference in the $\mathrm{pH}$ of the electrolytes. ${ }^{58,59}$ The specimens did not suffer either pitting or crevice corrosion in either electrolytes even after polarization to potentials higher than $800 \mathrm{mV}$ (SCE). ${ }^{58,59}$ No pitting or crevice corrosion was observed on Alloy 22 in $1 \mathrm{M} \mathrm{NaF}$ at pHs 6, 7.3 and 9 under both mill annealed and thermally aged conditions, the latter was performed to create conditions of full aging with TCP phases $\left(10 \mathrm{~h}\right.$ at $\left.760^{\circ} \mathrm{C}\right)$ and long range ordering ( $\mathrm{LRO}$ or $1000 \mathrm{~h}$ at $538^{\circ} \mathrm{C}$ ). In a recent study it was found that, in sufficient quantities, fluoride ions may also act as an inhibitor for the crevice corrosion of Alloy 22 in hot chloride solutions, probably because $\mathrm{HF}$ is a weaker acid than $\mathrm{HCl}$ and therefore the $\mathrm{pH}$ inside the crevices is not as low when fluoride ions are present in the electrolyte. ${ }^{60}$

In cyclic potentiodynamic polarization (CPP) tests carried out in $1 \mathrm{M} \mathrm{NaCl}$ and $1 \mathrm{M} \mathrm{NaBr}$ solutions at $50^{\circ} \mathrm{C}$, a slightly higher repassivation potential was reported for MA Alloy 22 in the bromide solution than in the chloride solution although both solutions had a similar $\mathrm{pH}$ of approximately $6 .{ }^{61}$ Under these tested conditions, neither pitting nor crevice corrosion was observed.

\section{Corrosion Underneath Deliquescent Brines}

At a given surface temperature, the existence of liquid water on the waste package surface depends upon the hygroscopic nature of any salt and mineral deposits on the surface. In the presence of such deposits, a thin liquid-phase surface brine film can be established at a higher temperature and lower relative humidity than otherwise possible. The chemistry-temperature-relative humidity stability range of this liquid phase brine film is modeled in the YMP. ${ }^{6}$ Environmental thermogravimetric analysis has also been used to study the corrosion of waste package material (Alloy 22) underneath deliquescent brines, and the evolution of acid gas due to the thermal decomposition of those brines. ${ }^{5}$ The subsequent weight loss is due to chemical transformations that are occurring in the aqueous solutions due to volatilization of $\mathrm{HCl}$. The accompanying $\mathrm{pH}$ increase causes precipitation of calcium containing species with the loss of the aqueous phase. Because of its lower corrosion resistance, Alloy 825 (UNS N08825) was tested in parallel with Alloy 22 to provide insight into localized modes of attack that might occur under deliquescent brine films. While substantial attack on Alloy 825 is evident, Alloy 22 has been shown to be resistant to localized attack under aggressive $\mathrm{CaCl}_{2}$ type deliquescent brines at $150^{\circ} \mathrm{C}$ and 22.5 percent relative humidity, suggesting there is no evidence of localized corrosion of Alloy 22 due to deliquescence. ${ }^{62}$

In more recent analysis it has been shown that it is likely that less than $10 \%$ of the dust collected on the waste package is going to be soluble salts. ${ }^{63}$ The salts in the dust will be mostly $\mathrm{NaCl}$ and $\mathrm{KNO}_{3}$ with smaller amounts of $\mathrm{NaNO}_{3}$ and $\mathrm{Ca}\left(\mathrm{NO}_{3}\right)_{2} \cdot{ }^{63}$ Mixtures of these salts may deliquesce at temperatures on the order of $160^{\circ} \mathrm{C} .{ }^{63}$ Even though if an aqueous solution forms by deliquescence of dust salts, the ratio of nitrate to chloride in the thin brine is going to be higher than 0.4 . A ratio of nitrate to chloride higher than 0.4 may be sufficient for inhibition of crevice corrosion. ${ }^{64,65}$ If a layer of brine forms, it may react to degas especially $\mathrm{HCl}$ and to a lesser extent $\mathrm{HNO}_{3} .{ }^{63}$ Moreover, if the aqueous solution persists, its volume may not be sufficient to initiate and sustain localized corrosion. ${ }^{63}$ 


\section{SUMMARY}

1. Alloy 22 (UNS N06022) is the material selected for the outer shell of the nuclear waste container for the Yucca Mountain repository.

2. Several modes of degradation for Alloy 22 are considered, including general corrosion, localized corrosion and stress corrosion cracking.

3. General Corrosion is not a limiting factor since the corrosion rates in the electrolytes simulating concentrated ground water are extremely low.

4. Localized corrosion may be the most detrimental mode of environmental degradation; however it is expected that the brines that may form at the site will be rich in nitrate and other compounds, which is an inhibitor for localized corrosion.

5. Alloy 22 is highly resistant to stress corrosion cracking; however, its occurrence will be limited since tensile stresses are planned to be removed from the outer surface of the container before emplacement.

6. Dust deliquescence may form concentrated brines at temperatures in the order of $160^{\circ} \mathrm{C}$. According to the composition and volume of the deliquescent brines, they may not be detrimental for the performance of the container.

\section{ACKNOWLEDGMENTS}

This work was partially performed under the auspices of the U. S. Department of Energy (DOE) by the University of California Lawrence Livermore National Laboratory under contract $\mathrm{N}^{\circ} \mathrm{W}-7405-$ Eng-48. 


\section{REFERENCES}

1. Baisden, P. A. and Atkins-Duffin, C. E. (2002), "Radioactive Waste Management," Chapter 7 in Handbook of Nuclear Chemistry (Lawrence Livermore National Laboratory, Report Number UCRL-JC-150549)

2. Nuclear Energy Agency (2003), "Engineered Barrier Systems and the Safety of Deep Geological Repositories," Organization for Economic Co-Operation and Development (OECD Publications, 2003: Paris, France)

3. Witherspoon, P. A. and Bodvarsson, G. S. (2001), "Geological Challenges in Radioactive Waste Isolation - Third Worldwide Review," Lawrence Berkeley Laboratory, Report LBNL-49767

4. BSC (2003), "Technical Basis Document No. 6: Waste Package and Drip Shield Corrosion," Las Vegas, Nevada, Bechtel SAIC Company, 2003.

5. BSC (Bechtel SAIC Company) 2004. Environment on the Surfaces of the Drip Shield and Waste Package Outer Barrier. ANL-EBS-MD-000001 Rev 01. Las Vegas, Nevada: Bechtel SAIC Company. ACC: DOC.20041116.0005.

6. BSC (Bechtel SAIC Company) 2004. Engineered Barrier System: Physical and Chemical Environment. ANL-EBS-MD-000033 REV 03. Las Vegas, Nevada: Bechtel SAIC Company. ACC: DOC.20041201.0001.

7. Harrar, J.E.; Carley, J.F.; Isherwood, W.F.; and Raber, E. 1990. Report of the Committee to Review the Use of J-13 Well Water in Nevada Nuclear Waste Storage Investigations. UCID-21867. Livermore, California: Lawrence Livermore National Laboratory.

8. Rosenberg, N.D.; Gdowski, G.E.; and Knauss, K.G. 2001. "Evaporative Chemical Evolution of Natural Waters at Yucca Mountain, Nevada." Applied Geochemistry, 16, ([9-10]), 1231-1240. [New York, New York]: Pergamon.

9. Sonnenthal, E.; Spycher, N.; Apps, J.; and Simmons, A. 1998. Thermo-Hydro-Chemical Predictive Analysis for the Drift-Scale Heater Test. Milestone SPY289M4. Version 1.0. Berkeley, California: Lawrence Berkeley National Laboratory.

10. Drever, J.I. 1997. "Evaporation and Saline Waters." Chapter 15 of The Geochemistry of Natural Waters: Surface and Groundwater Environments. 3rd Edition. Upper Saddle River, New Jersey: Prentice Hall.

11. Estill, J.C. 1998. "Long-Term Corrosion Studies." 2.2 of Engineered Materials Characterization Report. McCright, R.D., ed. UCRL-ID-119564 Volume 3 Rev.1.1. Livermore, California: Lawrence Livermore National Laboratory. ACC:

12. Plinski, M.J. 2001. Waste Package Operations Fabrication Process Report. TDR-EBS-ND000003 Rev 02. Las Vegas, Nevada: Bechtel SAIC Company. ACC: MOL.20011003.0025.

13. BSC (Bechtel SAIC Company) 2004. Stress Corrosion Cracking of the Drip Shield, the Waste Package Outer Barrier, and the Stainless Steel Structural Material. ANL-EBS-MD-000005 Rev 02. Las Vegas, Nevada: Bechtel SAIC Company. ACC: DOC.20041028.0008.

14. ASTM B 575. 2002. Standard Specification for Low-Carbon Nickel-Molybdenum-Chromium, Low-Carbon Nickel-Chromium-Molybdenum, Low-Carbon Nickel-Chromium-MolybdenumCopper, Low-Carbon Nickel-Chromium-Molybdenum-Tantalum, and Low-Carbon NickelChromium-Molybdenum-Tungsten Alloy Plate, Sheet, and Strip. West Conshohocken, Pennsylvania: American Society for Testing and Materials.

15. Hack, H.P. 1983. "Crevice Corrosion Behavior of Molybdenum-Containing Stainless Steels in Seawater." Materials Performance, 22, (6), 24-30. Houston, Texas: NACE International. 
16. Gruss, K.A.; Cragnolino, G.A.; Dunn, D.S.; and Sridhar, N. 1998. "Repassivation Potential for Localized Corrosion of Alloys 625 and C22 in Simulated Repository Environments." Proceedings of Corrosion 98, March 22-27, 1998, San Diego, California. Pages 149/1 to 149/15. Houston, Texas: NACE International.

17. Haynes International. 1997. Hastelloy C-22 Alloy and Hastelloy Alloy C-276, Haynes International Product Brochures, Kokomo, Indiana

18. ASTM B 2652002 Standard Specification for Titanium and Titanium Alloy Strip, Sheet and Plate. West Conshohocken, Pennsylvania: American Society for Testing and Materials.

19. BSC (Bechtel SAIC Company) 2004. Seismic Consequence Abstraction. MDL-WIS-PA-000003 Rev 01. Las Vegas, Nevada: Bechtel SAIC Company

20. BSC (Bechtel SAIC Company) 2004. Characterize Framework for Igneous Activity at Yucca Mountain, Nevada. ANL-MGR-GS-000001 Rev 02. Las Vegas, Nevada: Bechtel SAIC Company

21. BSC (Bechtel SAIC Company) 2004. Aging and Phase Stability of Waste Package Outer Barrier. ANL-EBS-MD-000002 Rev 02. Las Vegas, Nevada: Bechtel SAIC Company

22. BSC (Bechtel SAIC Company) 2004. General Corrosion and Localized Corrosion of Waste Package Outer Barrier. ANL-EBS-MD-000003 Rev 02. Las Vegas, Nevada: Bechtel SAIC Company.

23. Macdonald, D.D. 1992. "The Point Defect Model for the Passive State." Journal of the Electrochemical Society, 139, (12), 3434-3449. Manchester, New Hampshire: Electrochemical Society.

24. Macdonald, D.D. 1999. "Passivity-The Key to Our Metals-Based Civilization." Pure and Applied Chemistry, 71, (6), 951-978. Oxford, England: Blackwell Science.

25. Marcus, P. and Maurice, V. 2000. "Passivity of Metals and Alloys." Chapter 3 of Corrosion and Environmental Degradation. Schütze, M., ed. Volume I. Materials Science and Technology Volume 19. New York, New York: Wiley-VCH.

26. Lorang, G.; Jallerat, N.; Vu Quang, K.; and Langeron, J.-P. 1990. "AES Depth Profiling of Passive Overlayers Formed on Nickel Alloys." Surface and Interface Analysis, 16, 325-330. [Chiceter, England]: John Wiley \& Sons.

27. Urquidi, M. and Macdonald, D.D. 1985. "Solute-Vacancy Interaction Model and the Effect of Minor Alloying Elements on the Initiation of Pitting Corrosion." Journal of the Electrochemical Society, 132, (3), 555-558. [New York, New York]: Electrochemical Society.

28. Jones, D.A. 1992. Principles and Prevention of Corrosion. 1st Edition. New York, New York: Macmillan.

29. Welsch, G.; Smialek, J.L.; Doychak, J.; Waldman, J.; and Jacobson, N.S. 1996. "High Temperature Oxidation and Properties." Chapter. 2 of Oxidation and Corrosion of Intermetallic Alloys. Welsch, G. and Desai, P.D.; Eds. West Lafayette, Indiana: Purdue University.

30. ASM International. 1987. Corrosion. Volume 13 of ASM Handbook. Formerly 9th Edition, Metals Handbook. [Materials Park, Ohio]: ASM International.

31. Böhni, H. 2000. "Localized Corrosion of Passive Metals." Chapter 10 of Uhlig's Corrosion Handbook. Revie, R.W., ed. 2nd Edition. New York, New York: John Wiley \& Sons.

32. Dunn, D.S.; Cragnolino, G.A.; and Sridhar, N. 2000. "An Electrochemical Approach to Predicting Long-Term Localized Corrosion of Corrosion-Resistant High-Level Waste Container Materials." Corrosion, 56, (1), 90-104. Houston, Texas: National Association of Corrosion Engineers.

33. Dunn, D.S.; Yang, L.; Pan, Y.-M.; and Cragnolino, G.A. 2003. "Localized Corrosion Susceptibility of Alloy 22." Corrosion/2003, [58th Annual Conference \& Exposition, March 16-20, 2003, San Diego, California]. Paper No. 03697. Houston, Texas: NACE International.

34. Frankel, G.S. 1998. "Pitting Corrosion of Metals, A Review of the Critical Factors." Journal of the Electrochemical Society, 145, (6), 2186-2198. Pennington, New Jersey: Electrochemical Society. 
35. Frankel, G.S. 2002. "Localized Corrosion Phenomenology and Controlling Parameters." Section 6 of Waste Pack-age Materials Performance Peer Review, A Compilation of Special Topic Reports. Wong, F.M.G. and Payer, J.H., eds. Las Vegas, Nevada: Waste Package Materials Performance Peer Review Panel.

36. Frankel, G.S. and Kelly, R.G. 2002. "Passivity-Induced Ennoblement." Section 11 of Waste Package Materials Performance Peer Review, A Compilation of Special Topic Reports. Wong, F.M.G. and Payer, J.H., eds. Las Vegas, Nevada: Waste Package Materials Performance Peer Review Panel

37. Beavers, J.A.; Devine, T.M., Jr.; Frankel, G.S.; Jones, R.H.; Kelly, R.G.; Latanision, R.M.; and Payer, J.H. 2002. Final Report, Waste Package Materials Performance Peer Review Panel, February 28, 2002. [Las Vegas, Nevada]: Waste Package Materials Performance Peer Review Panel.

38. J. H. Lee, T. Summers and R. B. Rebak, Paper 04692, Corrosion/2004 (NACE International, 2004: Houston, TX).

39. Jayaweera, P.; Priyantha, N.; Macdonald, D.D.; Engelhard, G.; and Davydov, A. 2003. Deterministic Prediction of Lo-calized Corrosion Damage to Alloy C-22 HLNW Canisters. SRI Project 10333. Menlo Park, California: SRI International.

40. Ford, F.P. and Andresen, P.L. 1988. "Development and Use of a Predictive Model of Crack Propagation in 304/316L, A533B/A508 and Inconel 600/182 Alloys in $288^{\circ} \mathrm{C}$ Water." Environmental Degradation of Materials in Nuclear Power Systems - Water Reactors, Proceedings of the Third International Symposium, Traverse City, Michigan, August 30-September 3, 1987. Theus, G.J. and Weeks, J.R., eds. Pages 789-800, Warrendale, Pennsylvania: Metallurgical Society

41. Andresen, P.L. and Ford, F.L. 1985. "Modeling and Life Prediction of Stress Corrosion Cracking in Sensitized Stainless Steel in High-Temperature Water." Predictive Capabilities in Environmentally Assisted Cracking, Presented at the Winter Annual Meeting of the American Society of Mechanical Engineers, Miami Beach, Florida, November 17-22, 1985. Rungta, R., ed. PVP-Vol. 99. Pages 17-38. New York, New York: American Society of Mechanical Engineers.

42. S. C. Lu, G. M. Gordon and P. L. Andresen, "Validation of Stress Corrosion Cracking Model for High Level Radioactive-Waste Packages,” PVP-Vol. 483, Proceedings of the Conference in San Diego, CA 25-29 July 2004, p. 61 (ASME, 2004: New York, NY).

43. P. L. Andresen, G. M. Gordon and S. C. Lu, "The Stress-Corrosion Cracking Model for HighLevel Radioactive Waste Packages, JOM, January 2005, p. 27

44. Chen, H.-L.; Evans, K.J.; Hackel, L.A.; Rankin, J.E.; Yamamoto, R.M.; Demma, A.G.; Dewald, A.T.; Lee, M.J.; and Hill, M.R. 2002. Mitigation of Tensile Weld Stresses in Alloy 22 Using Laser Peening. UCRL-ID-151055. Livermore, California: Lawrence Livermore National Laboratory

45. Gdowski, G.E. 1991. Survey of Degradation Modes of Four Nickel-Chromium-Molybdenum Alloys. UCRL-ID-108330. Livermore, California: Lawrence Livermore National Laboratory

46. Asphahani, A.I. [1978]. "Hydrogen Cracking of Nickel-Base Alloys." Hydrogen in Metals, [Proceedings of the] 2nd International Congress, [Paris, France, 6-10 June, 1977]. [1], Paper 3C2. [New York, New York: Pergamon].

47. BSC (Bechtel SAIC Company) 2004. FEPs Screening of Processes and Issues in Drip Shield and Waste Package Degradation. ANL-EBS-PA-000002 Rev 03. Las Vegas, Nevada: Bechtel SAIC Company

48. Hua, F.; Mon, K.; Pasupathi, V.; Gordon, G.; and Shoesmith, D. 2004. "Corrosion of Ti Grade 7 and Other Ti Alloys in Nuclear Waste Repository Environments - A Review." Corrosion/2004, 59th Annual Conference \& Exposition, March 28-April 1, 2004, New Orleans. Paper No. 04689. Houston, Texas: NACE International.

49. Glass, R.S.; Overturf, G.E.; Van Konynenburg, R.A.; and McCright, R.D. 1986. "Gamma Radiation Effects on Corrosion-I. Electrochemical Mechanisms for the Aqueous Corrosion Processes 
of Austenitic Stainless Steels Relevant to Nuclear Waste Disposal in Tuff." Corrosion Science, 26, (8), 577-590. Oxford, Great Britain: Pergamon.

50. Kim, Y.J. 1987. "Effect of Gamma Radiation on Electrochemical Behavior of 9 Cr-1Mo Alloy in $\mathrm{NaCl}$ Solutions." Journal of the Corrosion Science Society of Korea, 16, (1), 25-30. Seoul, Korea: Corrosion Science Society of Korea.

51. Shoesmith, D.W. and King, F. 1998. The Effects of Gamma Radiation on the Corrosion of Candidate Materials for the Fabrication of Nuclear Waste Packages. AECL-11999. Pinawa, Manitoba, Canada: Atomic Energy of Canada Limited.

52. Dose Rate Calculation for 21-PWR Waste Package. 000-00C-DSU0-01800-000-00A. Las Vegas, Nevada: Bechtel SAIC Company.

53. Fontana, M.G. 1986. Corrosion Engineering. 3rd Edition. New York, New York: McGraw-Hill.

54. Lian, T.; Jones, D.; Martin, S.; and Horn, J. 1999. "A Quantitative Assessment of Microbiological Contributions to Corrosion of Candidate Nuclear Waste Package Materials." Scientific Basis for Nuclear Waste Management XXII, Symposium held November 30-December 4, 1998, Boston, Massachusetts. Wronkiewicz, D.J. and Lee, J.H., eds. 556, 1175-1182. Warrendale, Pennsylvania: Materials Research Society

55. Stoecker, J.G., II. 1987. "Evaluation of Microbiological Corrosion." In Corrosion, Volume 13, Pages 314-315 of Metals Handbook. 9th Edition. Metals Park, Ohio: ASM International.

56. Horn, J. and Jones, D. 2002. "Microbiologically Influenced Corrosion: Perspectives and Approaches." Manual of Environmental Microbiology. 2nd Edition. Hurst, C.J., ed. Pages 10721083. Washington, D.C.: ASM Press.

57. N. S. Meck, P. Crook, S. D. Day and R. B. Rebak, Paper 03682, Corrosion/2003 (NACE International, 2003: Houston, TX)

58. M. A. Rodríguez, R. M. Carranza and R. B. Rebak, Paper 04700, Corrosion/2004 (NACE International, 2004: Houston, TX)

59. M. A. Rodríguez, R. M. Carranza and R. B. Rebak, Met. Trans A, Vol. 36A, p. 1179 (2005).

60. R. M. Carranza, M. A. Rodríguez and R. B. Rebak, Paper 06626, Corrosion/2006 (NACE International, 2006: Houston, TX)

61. R. B. Rebak, N. E. Koon, J. P. Cotner and P. Crook, ECS PV 99-27, p. 473 (The Electrochemical Society, 1999: Pennington, NJ)

62. Farmer, J. 2003. Materials Performance. Presentation to the Nuclear Waste Technical Review Board, May 13, 2003, Washington, D.C. Las Vegas, Nevada: Bechtel SAIC Company.

63. R. W. Andrews, "Science and Modeling Update." Presentation to the Nuclear Waste Technical Review Board, 09 February 2005, Las Vegas, NV. Las Vegas, Nevada: Bechtel SAIC Company.

64. D. S. Dunn, L. Yang, C. Wu and G. A. Cragnolino, Mat. Res. Soc. Symp. Proc. Vol 824 (MRS, 2004: Warrendale, PA)

65. D. S. Dunn, Y.-M. Pan, K. Chiang, L. Yang, G. A. Cragnolino and X. He "Localized Corrosion Resistance and Mechanical Properties of Alloy 22 Waste Package Outer Containers" JOM, January 2005 (TMS, 2005: Warrendale, PA) 
TABLE 1

TARGET COMPOSITION OF STANDARD TEST MEDIA BASED ON EVAPORATIVE CONCENTRATION OF A DILUTE CARBONATE TYPE WATER (J-13)

\begin{tabular}{|l|c|c|c|c|c|}
\hline Ion & $\begin{array}{c}\text { SDW } \\
(\mathrm{mg} / \mathrm{L})\end{array}$ & $\begin{array}{c}\mathrm{SCW} \\
(\mathrm{mg} / \mathrm{L})\end{array}$ & $\begin{array}{c}\mathrm{SAW} \\
(\mathrm{mg} / \mathrm{L})\end{array}$ & $\begin{array}{c}\mathrm{SSW} \\
(\mathrm{mg} / \mathrm{L})\end{array}$ & $\begin{array}{c}\mathrm{BSW}-12 \\
(\mathrm{mg} / \mathrm{L})\end{array}$ \\
\hline & $3.4 \times 10^{1}$ & $3.4 \times 10^{3}$ & $3.4 \times 10^{3}$ & $1.42 \times 10^{5}$ & $6.762 \times 10^{4}$ \\
\hline $\mathrm{K}^{+}$ & $4.09 \times 10^{2}$ & $4.09 \times 10^{4}$ & $3.769 \times 10^{4}$ & $4.87 \times 10^{4}$ & $1.0584 \times 10^{5}$ \\
\hline $\mathrm{Na}^{+}$ & 1 & $<1$ & $1.00 \times 10^{3}$ & 0 & 0 \\
\hline $\mathrm{Mg}^{2+}$ & $5 \times 10^{-1}$ & $<1$ & $1.00 \times 10^{3}$ & 0 & 0 \\
\hline $\mathrm{Ca}^{2+}$ & $1.4 \times 10^{1}$ & $1.4 \times 10^{3}$ & 0 & 0 & $1.47 \times 10^{3}$ \\
\hline $\mathrm{F}^{-}$ & $6.7 \times 10^{1}$ & $6.7 \times 10^{3}$ & $2.425 \times 10^{4}$ & $1.28 \times 10^{5}$ & $1.3083 \times 10^{5}$ \\
\hline $\mathrm{Cl}^{-}$ & $6.4 \times 10^{1}$ & $6.4 \times 10^{3}$ & $2.30 \times 10^{4}$ & $1.313 \times 10^{6}$ & $1.3965 \times 10^{6}$ \\
\hline $\mathrm{NO}_{3}{ }^{-}$ & $1.67 \times 10^{2}$ & $1.67 \times 10^{4}$ & $3.86 \times 10^{4}$ & 0 & $1.47 \times 10^{4}$ \\
\hline $\mathrm{SO}_{4}{ }^{2-}$ & $9.47 \times 10^{2}$ & $7.0 \times 10^{4}$ & 0 & 0 & 0 \\
\hline $\mathrm{HCO}_{3}{ }^{-}$ & $27\left(60^{\circ} \mathrm{C}\right)$ & $27\left(60^{\circ} \mathrm{C}\right)$ & $27\left(60^{\circ} \mathrm{C}\right)$ & 0 & 0 \\
\hline $\mathrm{SiO}_{2}$ (aq.) & $49\left(90^{\circ} \mathrm{C}\right)$ & $49\left(90^{\circ} \mathrm{C}\right)$ & $49\left(90^{\circ} \mathrm{C}\right)$ & & \\
\hline $\mathrm{pH}$ & 9.8 to 10.2 & 9.8 to 10.2 & 2.7 & 5.5 to 7 & 12 \\
\hline
\end{tabular}




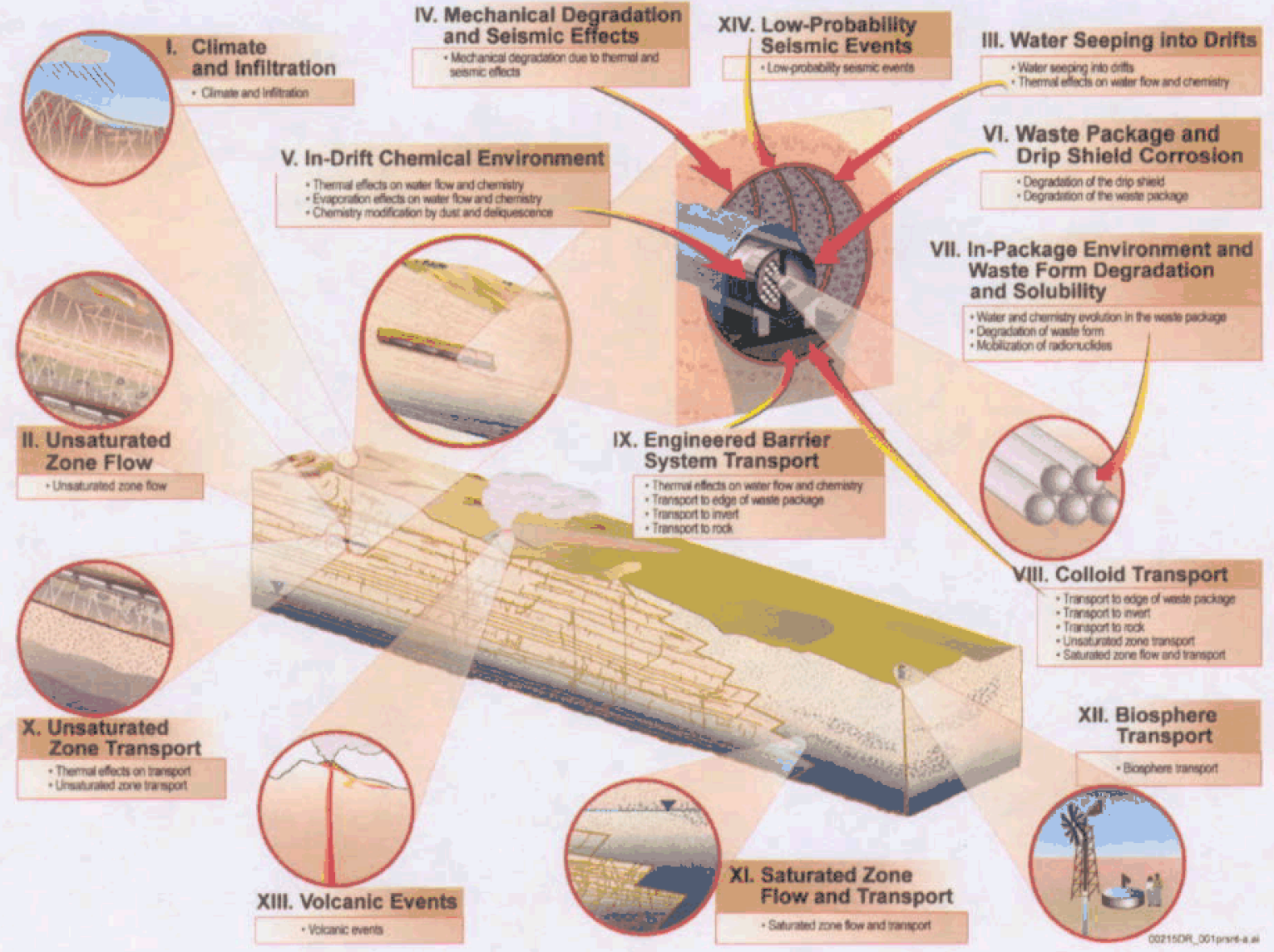

FIGURE 1 - Components of the Yucca Mountain Repository 


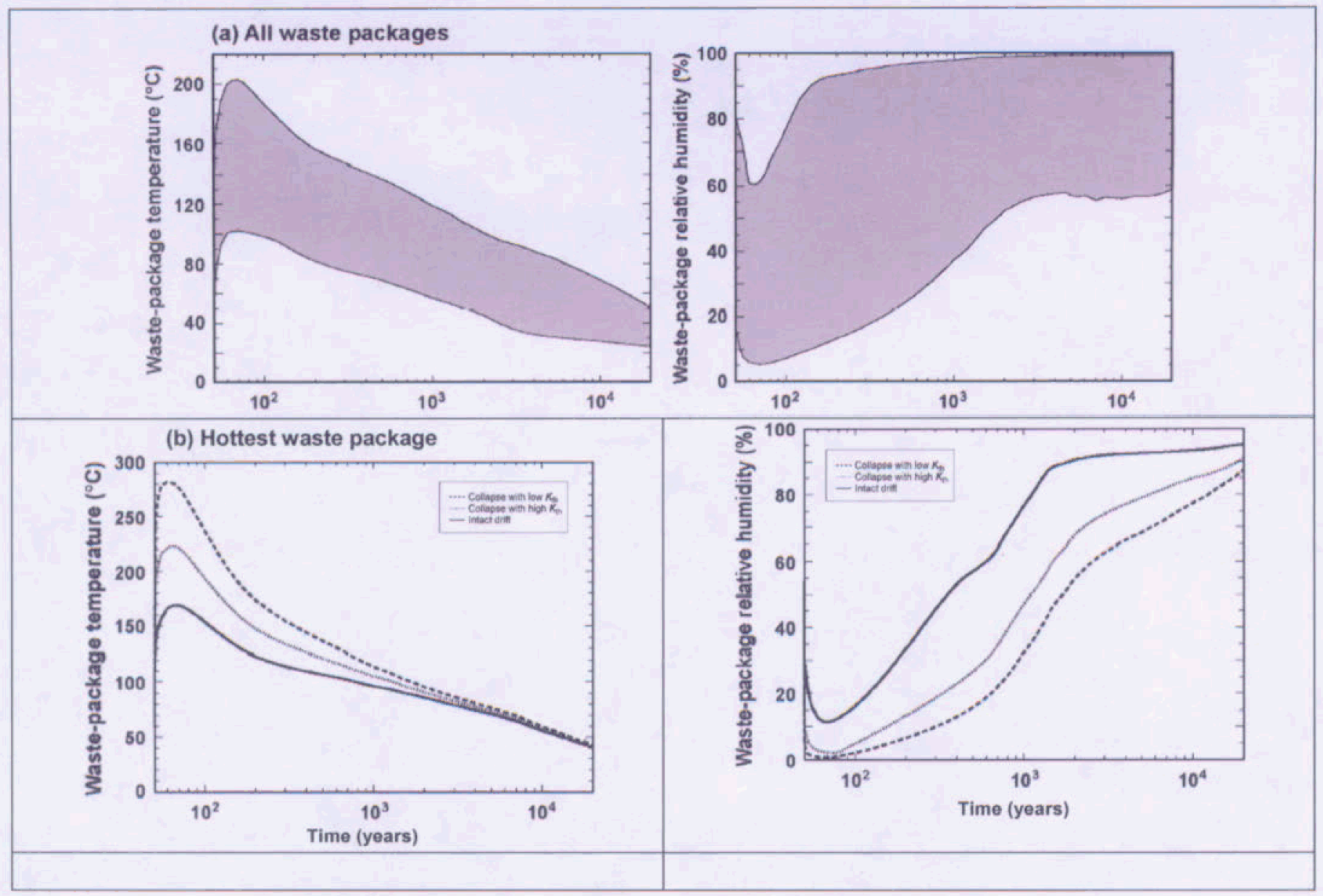

FIGURE 2 - Waste package temperature and relative humidity ranges: (a) for all waste packages in the nominal scenario and (b) for the "hottest" waste package in the low-probability seismic collapsed drift scenario
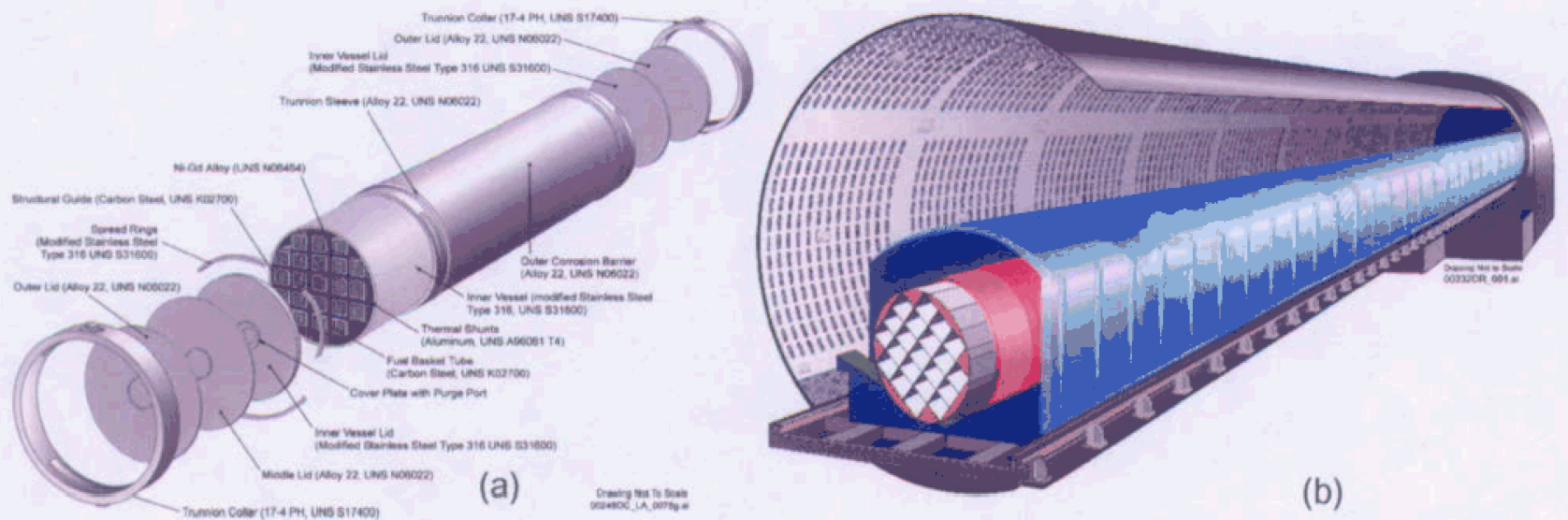

FIGURE 3 - Schematic Illustrations of Current Designs of the (a) Waste Package and (b) Drip Shield in the Yucca Mountain Repository 


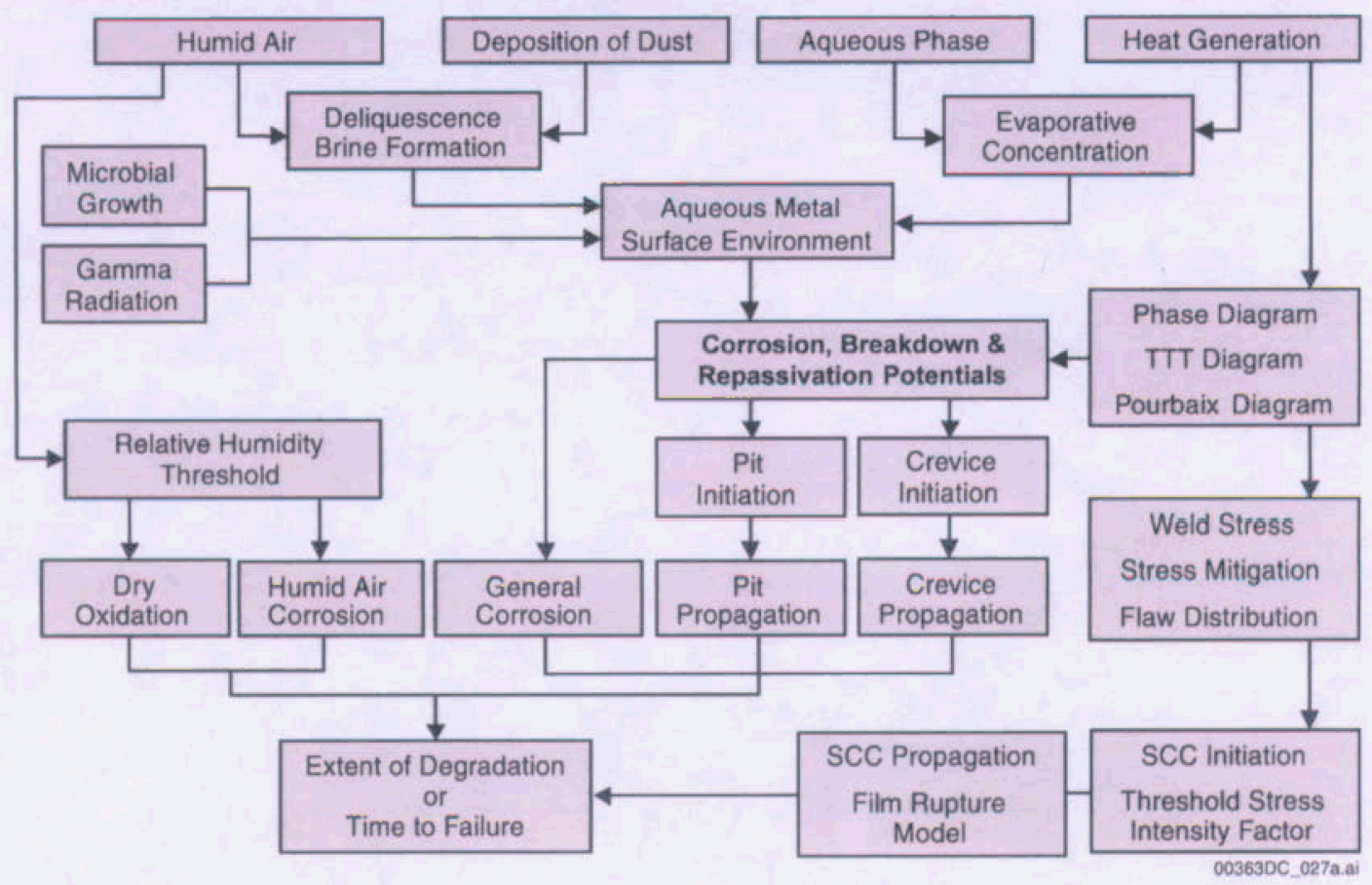

FIGURE 4 - Systematic Interactions between the In-Drift Environment and the Drip Shield and Waste Package Outer Shell Resulting in the Occurrence of Various Degradation Modes ${ }^{4}$

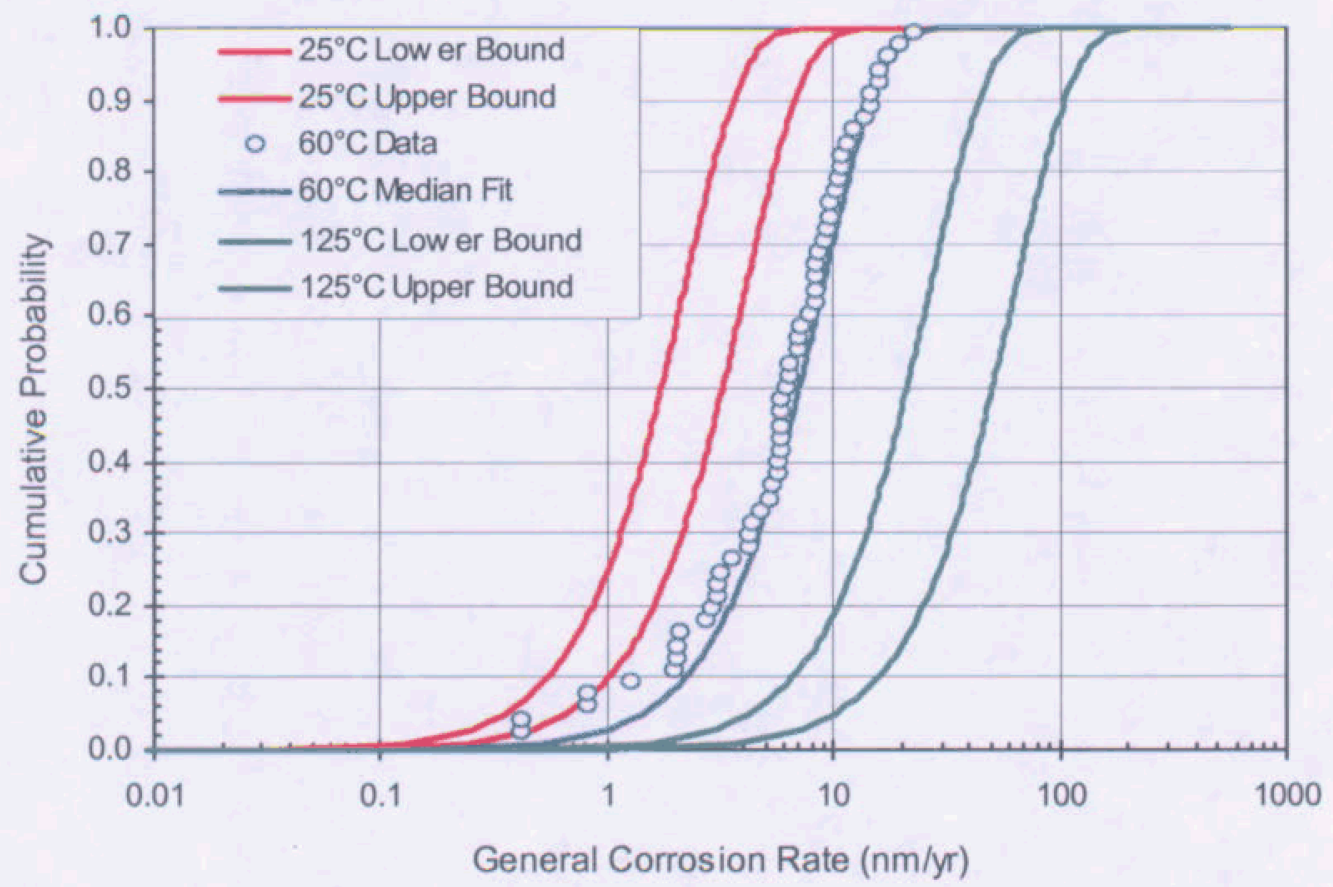

FIGURE 5 - General Corrosion Rates Distributions for Waste Package Outer Shell 


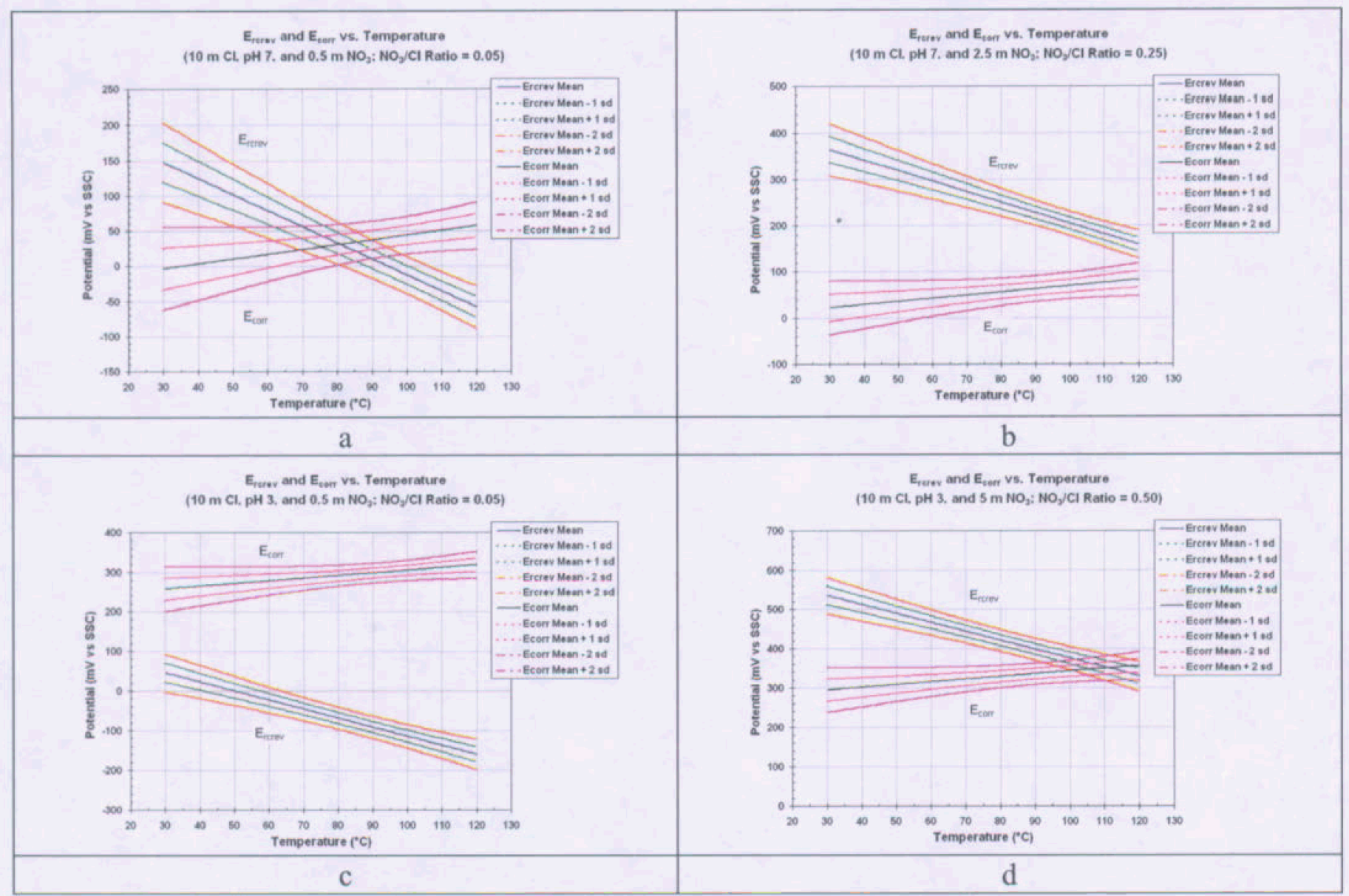

FIGURE 6 - Model results as a function of temperature for $10 \mathrm{~m}$ chloride solutions. In (a) $\mathrm{pH}=7$ and nitrate ion concentration is $0.5 \mathrm{~m}$ and in (b) $\mathrm{pH}=7$ and nitrate ion concentration is $2.5 \mathrm{~m}$. In (c) $\mathrm{pH}=3$ and nitrate ion concentration is $0.5 \mathrm{~m}$ and in (d) $\mathrm{pH}=3$ and nitrate ion concentration is $5 \mathrm{~m}$. 

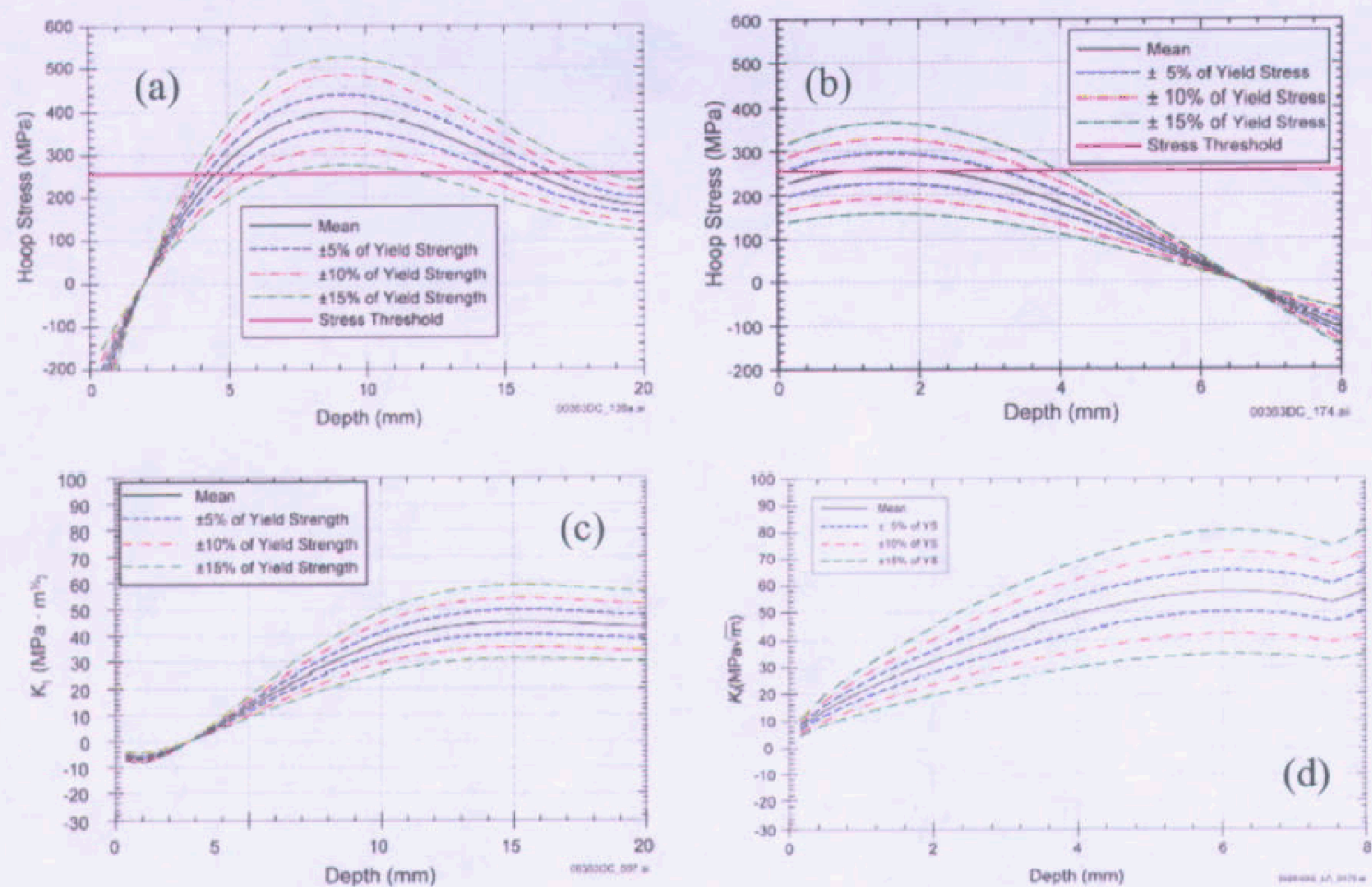

FIGURE 7 - (a) Hoop stress versus depth for laser-peened outer closure lid weld region with uncertainty, (b) Hoop stress versus depth for as-welded middle closure lid weld region with uncertainty, (c) Stress intensity factor versus depth for laser peened outer closure lid weld region with uncertainty, and (d) Stress intensity factor versus depth for as-welded middle closure lid weld region with uncertainty ${ }^{13}$

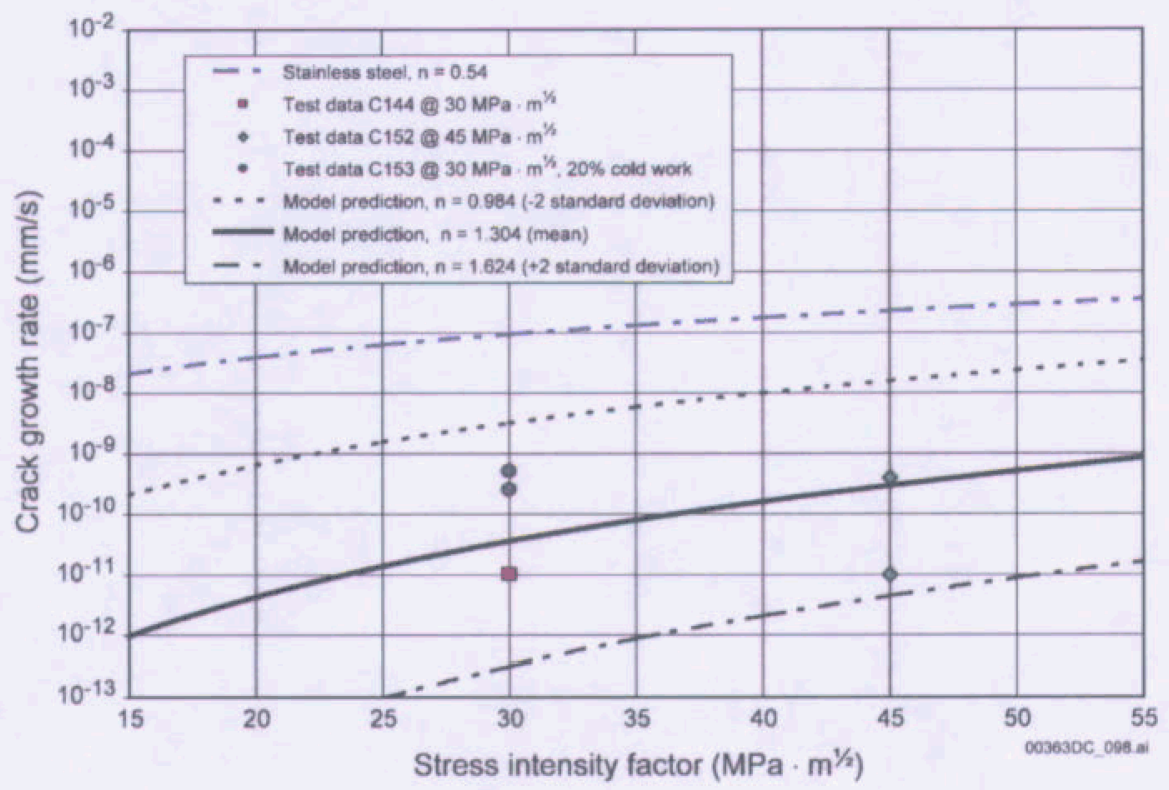

FIGURE 8 - Predicted crack-growth rate for the SCC of Alloy 22 as a function of stress intensity factor for bounding values of the repassivation slope, $n$ 